Scientia Agricola

http://dx.doi.org/10.1590/1678-992X-2016-0135

\title{
Sustained swimming improves fish dietary nutrient assimilation efficiency and body composition of juvenile Brycon amazonicus
}

\author{
Gustavo Alberto Arbeláez-Rojas* , Gilberto Moraes
}

Federal University of São Carlos - Dept. of Genetics and Evolution, Rod. Washington Luis, km 235 - 13565-905 São Carlos, SP - Brazil.

*Corresponding author <matamba2@yahoo.com.br>

Edited by: Paulo Cesar Sentelhas

\begin{abstract}
Sustained swimming (SS) usually promotes beneficial effects in growth and feed conversion of fishes. Although feed efficiency is improves at moderate water velocity, more information is required to determine the contributions of this factor on growth and body composition. Body composition and efficiency responses to the use of nutrients were determined in juvenile matrinxa Brycon amazonicus (Spix and Agassiz, 1829) fed with two dietary amounts of protein, 28 or $38 \%$ of crude protein (CP), and subjected to sustained swimming at a constant speed of 1.5 body lengths $\mathrm{s}^{-1}\left(\mathrm{BL} \mathrm{s}^{-1}\right)$ or let to free swimming. The fish body composition under SS and fed with $28 \%$ of dietary protein showed $22 \%$ of increased in bulk protein and a $26 \%$ of decrease in water content in the white muscle. Red muscle depicted $70 \%$ less water content and a $10 \%$ more lipid. Nutrient retention was enhanced in fish subjected to SS and a higher gain of ethereal extract sustained was observed in the white muscle of exercised fish fed with $38 \%$ CP. The interaction between swimming and dietary protein resulted in a larger bulk of lipid in red muscle. Fish fed with $28 \% \mathrm{CP}$ under SS at $1.5 \mathrm{BL} \mathrm{s}^{-1}$ presented the best utilization of dietary nutrients and body composition. Thus, this fish farming procedure is proposed as a promising management strategy for rearing matrinxa.
\end{abstract}

Keywords: benefits of exercise, dietary protein, nutrient retention, optimal swimming speeds, raceways trout). Matrinxa demands good quality water and is adaptable to high stocking densities and artificial feeding (Abreu et al., 2008; Arbelaéz-Rojas and Moraes, 2009; Cruz-Casallas et al., 2011). It is a migratory streamlined fish (Mounic-Silva and Leite, 2012), whose phenotypic traits have encouraged studies on adaptive responses to SS and growth performance.

Despite the existence of studies with matrinxa under SS (Hackbarth and Moraes, 2006), data on the efficiency of dietary nutrient assimilation under exercise do not exist for this fish. Interactions between nutritional conditions and the rearing of fish under SS may enhance their growth performance. This manuscript addresses the evaluation of body composition and assimilation efficiency of food components (protein, lipids and carbohydrates) by matrinxa at two levels of dietary protein and sustained swimming.

\section{Materials and Methods}

swimming (SS) has emerged as a promising alternative for increasing muscular mass.

Salmonids reared under SS at moderate speeds are a good example of success (Nahhas et al., 1982; Houlihan and Laurent, 1987; Totland et al., 1987; Christiansen et al., 1989; Grisdale-Helland et al, 2013). Similarly, matrinxa Brycon amazonicus (Spix and Agassiz, 1829) shows real promise (Hackbarth and Moraes, 2006; Arbeláez-Rojas and Moraes, 2009; Cruz-Casallas et al., 2011) for fish farming. Since muscle protein and lipid bulks are related to body energy and resistance to environmental changes, their enhancement should be explored (Young and Cech, 1994). The omnivorous freshwater fish matrinxa has proven to be commercially exploitable due to its many biological traits (which earned it the alias warm water

\section{Experimental design}

This study was conducted in São Carlos, in the state of São Paulo, Brazil ( $820 \mathrm{~m}$ alt., $21^{\circ} 58^{\prime} \mathrm{S}$ and $47^{\circ} 51^{\prime} \mathrm{W}$ ). Around 300 juvenile matrinxa were obtained from the Águas Claras commercial fish farm, located in Mococa, in the state of Sao Paulo, Brazil. Fish were kept in 2.000 $\mathrm{L}$ tanks of flowing water under natural photoperiod for 3 weeks to facilitate acclimatization to the experimental conditions $\left(27{ }^{\circ} \mathrm{C}\right.$ and $5 \mathrm{mg} \mathrm{L}^{-1}$ dissolved oxygen). During this time, they were fed with commercial pellets until satiety. After acclimatization, 240 fish were selected for uniform weight and size between 28.5 to $30.5 \mathrm{~g}$ and 12 
to $14 \mathrm{~cm}$, respectively. They were equally divided into 12 groups (20 fish per group) and randomly transferred and held in circular fiberglass tanks of $250 \mathrm{~L}$. Tanks water were thermostated, filtered through biobeds, and kept under continuous aeration in a recirculation closed-system. Six tanks were assigned as sustained swimming (SS) and the fish were encouraged to swim at a water speed of 1.5 body length per second $\left(\mathrm{BL} \mathrm{s}^{-1}\right)$ for over 60 days. In the other six tanks, assigned as resting (R), the water was motionless and no swimming was imposed to the fish. Tanks $\mathrm{SS}$ and $\mathrm{R}$ were divided into two groups of three tanks and two protein levels were chosen and ascribed as L (low level of protein) and $\mathrm{H}$ (high level of protein).

Prior to the experiment, 10 fish (weight and size of $29.2 \pm 1.22 \mathrm{~g}$ and $13 \pm 1.2 \mathrm{~cm}$, respectively) from the original set of acclimatized fish were randomly collected and euthanized with $40 \mathrm{mg} \mathrm{L}^{-1}$ eugenol (Inoue et al., 2003). This line of research had been approved by the Animal Experimentation Ethics Committee of the Federal University of São Carlos in November, 2009. Samples of white and red muscles were excised and kept at $-20{ }^{\circ} \mathrm{C}$ for determination of nutrient utilization efficiency based on the initial and final body composition analyses. The fish were fed to satiety three times a day for 60 days. Extruded pellets were offered as isocaloric diets of $4.100 \mathrm{kcal} \mathrm{kg}^{-1}$ (Table 1).

Table 1 - Formulation and chemical composition of the experimental diets for the feeding of Brycon amazonicus.

\begin{tabular}{|c|c|c|}
\hline \multirow{2}{*}{ Ingredient (g \%) } & \multicolumn{2}{|c|}{ Dietary protein levels (g \%) } \\
\hline & 28 & 38 \\
\hline Fishmeal & 23.50 & 32.00 \\
\hline Soybean meal & 18.00 & 32.68 \\
\hline Corn & 51.48 & 28.30 \\
\hline Grinded rice & 3.00 & 3.00 \\
\hline Yeast & 1.00 & 1.00 \\
\hline Soybean oil & 1.00 & 1.00 \\
\hline Mineral and vitamin supplement ${ }^{1}$ & 2.00 & 2.00 \\
\hline Salt & 0.02 & 0.02 \\
\hline \multicolumn{3}{|l|}{ Chemical composition (g \%) } \\
\hline Dry matter & 88.63 & 88.99 \\
\hline Gross energy (kcal kg-1) & 3920.1 & 3981.1 \\
\hline Crude protein & 28.01 & 38.00 \\
\hline Carbohydrate $^{2}$ & 44.98 & 32.84 \\
\hline Crude fiber & 2.22 & 2.57 \\
\hline Mineral matter & 6.64 & 8.86 \\
\hline Ether Extract & 4.83 & 4.77 \\
\hline Phosphorus & 1.15 & 1.57 \\
\hline Calcium & 0.81 & 1.06 \\
\hline Ascorbic acid & 0.05 & 0.05 \\
\hline \multicolumn{3}{|c|}{ 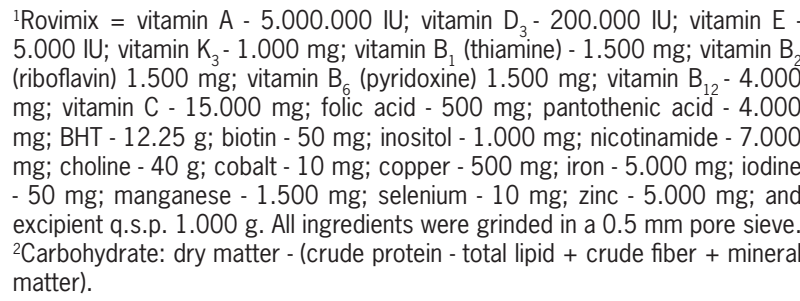 } \\
\hline
\end{tabular}

After the experimental period, fish feeding was discontinued for $24 \mathrm{~h}$ for gastric emptying; and six fish from each tank (18 fish per condition) were sampled. Biometry was performed and samples of white and red muscle were collected for body composition analyses. The samples were promptly frozen at $-20{ }^{\circ} \mathrm{C}$ and lyophilized for posterior determination of the body protein (BP) content, crude energy (CE), ethereal extract (EE) and dry matter (DM), according to AOAC (1990). The Retention Efficiency expression of wet matter was $\mathrm{RE}_{M}$ $=\left\{\left[\left(M_{F} \times W_{F}\right)-\left(M_{I} \times W_{I}\right)\right] / C M\right\} 100$, where $M_{F}=$ Final matter; $\mathrm{W}_{\mathrm{F}}=$ Alive final weight; $\mathrm{M}_{\mathrm{I}}=$ Initial matter; $\mathrm{W}_{\mathrm{I}}$ = Initial weight; and $\mathrm{CM}=$ Consumed matter was used for determining nutrient utilization efficiency.

\section{Sustained swimming system}

The swimming system consisted of bottom-funnelshaped fiber glass tanks with horizontal leaning $\left(20^{\circ}\right)$ from the side to a central sewer hole, which enables easy clearance of debris. The water was biologically filtered and thermostated and re-fed to the tanks through drill bored L-shaped pipes fitted into the water column, to maintain the speed reached by a $3 / 4$ HP pump inserted into the line and adjusted by a control valve. The water speed was gauged by a mechanical flow meter. Since tangential water speed decreases from the edge to the center, the fish were prevented from accessing the central water region by a top-to-bottom PVC net column,1/3 of the total tank diameter; the narrower the column of water let for swimming the more regular the swimming speed. The choice of a water flux corresponding to a swimming speed of $1.5 \mathrm{BL} \mathrm{s}^{-1}$ was based on previous studies (Arbeláez-Rojas and Moraes, 2010).

\section{Statistics}

Data were analyzed by a two-way ANOVA with protein levels and rearing conditions (SS at a constant speed of $1.5 \mathrm{BL} \mathrm{s}^{-1}$ or resting). The statistical significance was set at a $5 \%$ probability level and means were separated using the Tukey test. Sample homogeneity was statistically assured at $p<0.05$. Statistical Analysis System -SAS Institute Inc., Cary, NC, USA Software 9.3, 2010 was used. The data are presented in terms of means \pm (S.D.).

\section{Results and Discussion}

Table 2 shows the statistical analyses by $\mathrm{F}$ test and the mean comparison by the Tukey test $(p<0.05)$ of each factor for the centesimal composition parameters of white and red muscle of $B$. amazonicus. An increase in dietary $\mathrm{CP}$ reduced the white muscle protein and moisture. However, dietary CP did not alter the centesimal composition parameters of the red muscle. The SS stimulated the increase of $\mathrm{CP}, \mathrm{EE}$ and $\mathrm{CE}$ and reduced moisture content in the white muscle. The red muscle exhibited a similar pattern of responses. Dietary CP and the rearing condition (Sustained swimming) significantly 
interacted for certain centesimal composition parameters of the muscle of $B$. amazonicus (Table 2). In the white muscle, both $\mathrm{CP}$ and moisture were affected by the interaction of the factors, whereas in red muscle this response was observed for moisture and EE levels. Occurrence of factor interaction (Table 2) resulted in the highest $\mathrm{CP}(22 \%)$ and the lowest moisture $(74 \%)$ of the white muscle of fish reared in SS and fed with $28 \%$ of CP. Moreover, the largest deposition of EE (11 \%) and lowest moisture $(71 \%)$ were observed in the red muscle, which shows that such factors either isolated or in combination can alter body composition at different degrees. Several studies have focused on the evaluation of an isolated factor. For instance, the performance of Brycon orbignianus (piracanjuba) was evaluated when this fish was fed with six levels of $\mathrm{CP}$, from 24 to $42 \%$, and curiously, the degree of body protein was not altered (Sá and Fracalossi, 2002). Posteriorly, matrinxa juveniles fed with $\mathrm{CP}$ varying from 16 to $28 \%$ exhibited the same response pattern in a study by Izel et al. (2004). In both studies, the fishes were reared in conventional systems of motionless water. In addition, no significant differences were observed in the bromatological evaluation of the fillet, which is assumed to be related to steady, dietary energy levels. Nevertheless, an increase in either fat or crude energy following the increase of dietary $\mathrm{CP}$ was found for the fillet of matrinxa juveniles. This finding suggests that protein was the primary nutrient for growth and that it was under endogenous control, and is thus less likely to be affected by other nutrients (Shearer, 1994; Jobling et al., 1998). Other body components, such as lipids, carbohydrates, and even water are more susceptible to oscillations in response to environmental or nutritional factors.

A synergistic effect between $\mathrm{CP}$ and SS that depends on the exercise span, dietary composition, and species' traits (Davison, 1997; Christiansen et al., 1989; Jørgensen and Jobling, 1993) was observed for the juvenile matrinxa resulting in protein deposition in the natatory muscles. Some changes in body composition in fish reared under SS were also found. For example, certain migratory species before spawning, or skilled swimmers, such as salmonids, increase their body protein (Totland et al., 1987; Christiansen et al., 1989). Fish species under water stream at increasing velocities usually show decreasing levels of body lipids in response to the energetic demand of locomotory muscles (Jørgensen and Jobling, 1993).

Juvenile matrinxa reared under SS at stocking densities from 88 to 353 fish $\mathrm{m}^{-3}$ maintained both fat and protein in the white muscle increasing to a density of 176 fish m$^{-3}$ (Arbeláez-Rojas and Moraes, 2009). It is argued that high fish densities (353 fish $\mathrm{m}^{-3}$ ) result in carcasses of low quality probably due to the lessening of nutrient utilization. The fish density used in our experiments was not high enough to impair the benefits of SS.

Results from the statistics by F-test and the measurements of the energy and nutrient assimilation effi- 
ciency compared by Tukey test $(p<0.05)$ are shown in Table 3 for each factor. From all evaluated parameters only ethereal extract on the weight gain of white muscle $\left(\mathrm{EE}_{\mathrm{WG}}\right)$ was positive and significantly affected by the synergistic interaction between CP and SS (Table 3).

The increase in dietary $\mathrm{CP}$ resulted in enhancement of $\mathrm{EE}_{\mathrm{WG}}$. However, that variable was more responsive to the SS. This fact suggests a synergistic effect between such factors, whereas SS increases the lipid gain. This was easily observed in the white muscle of $B$. amazonicus reared under SS and fed with $38 \% \mathrm{CP}$ in which the EE gain was the highest.

The results suggest that dietary $\mathrm{CP}$ above $38 \%$ is excessive for juvenile matrinxa. While in fish living under motionless water the protein surplus would likely lead to muscular fat, in exercised ones its deposition was amplified. However, prior to the swimming physical efforts, some fish species accumulated lipids whenever they were fed with nutrients in excess (Felip et al., 2012; $\mathrm{Li}$ et al., 2013). Therefore, the body composition changes observed in fish under SS are not always the same, since many factors, such as diet quality, feeding practices, fish species, swimming intensity and span can be involved (Davison, 1997; Yogata and Oku, 2000; Felip et al., 2013).

The main significant differences observed in matrinxa were concerned with the type of farming. Fish reared under SS showed a nutrient retention efficiency superior to that observed in fish farmed under the conventional rearing system with motionless water (Table 3). The efficiency of nutrient retention in the white muscle of fish reared under SS was higher than that of red muscle. In particular, the white muscle of matrinxa was more responsive to SS and the level of dietary protein, concerning the efficiency of protein retention. Matrinxa fed with $28 \% \mathrm{CP}$ under SS showed better protein retention efficiency and higher weight gain, i.e., an increase in the muscle production. This fact can be attributed to the exercise effect on the protein synthesis rates and storage, and turnover of muscle fibers, which are directly related to their size or the muscle hypertrophy (Totland et al., 1987; Davison, 1997). The increase of white muscle mass in fish can be driven by several environmental factors, including exercise (Videler, 2011), which induces beneficial changes in body composition, especially muscle mass, because of the higher efficiency on protein utilization (Palstra and Planas, 2011). For example, Sparus aurata reared under SS retains more protein in white muscle, as observed in fish fed with isotope labeled nutrients (Felip et al., 2013).

Other responses of fish reared under SS can contribute to increasing the utilization efficiency of nutrient such as a reduction in aggressiveness. Atlantic salmon Salmo salar, reared under SS at 1.0 to $1.75 \mathrm{BL} \mathrm{s}^{-1} \mathrm{im}$ prove the efficiency of food utilization as a consequence of reduced aggressiveness (Christiansen and Jobling, 1990; Jobling et al., 1993). Non-exercised fish exhibit higher oxygen consumption due to the high antagonistic activity, which results in less food assimilation ef-

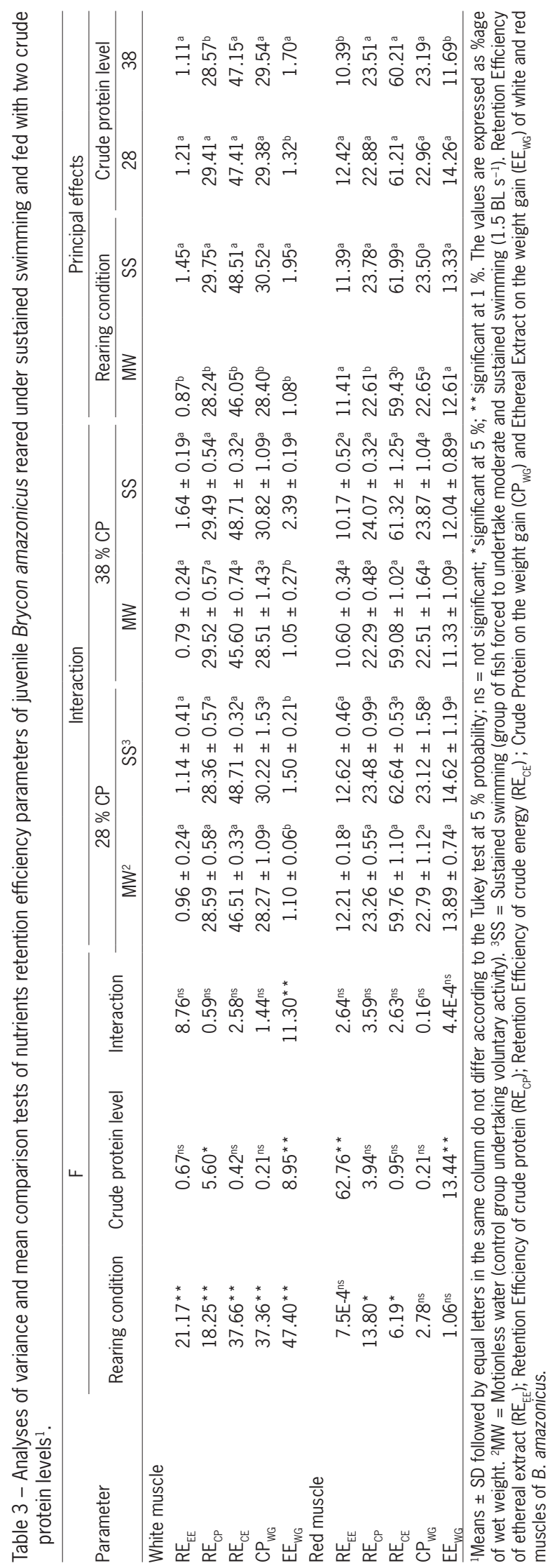


ficiency. The results show that SS is relevant to sparing the dietary protein, i.e., fish reared under SS at moderate water speeds assimilate nutrients from the diet more efficiently than those reared in motionless water. Moreover, proteins are the main component in diet cost, and levels above that required for the species, besides being more expensive, increase the metabolic cost and generate high levels of nitrogen excretion, which eventually deteriorate the water quality. Therefore, the sparing effect from SS was beneficial for the sustainability of the farming of matrinxa and reduced the environmental impact of production costs.

Like the white muscle, the red muscle of fish held under SS displayed protein and energy retention values greater than those that were observed in fish reared in motionless water. However, the $\mathrm{RE}_{\mathrm{EE}}$ in the red muscle of matrinxa fed with $28 \% \mathrm{CP}$ were higher than those observed in fish fed with $38 \% \mathrm{CP}$. Such enhanced CP retention efficiency of fish fed with $28 \%$ CP under SS suggests an adaptive mechanism to utilize dietary protein in a more efficient way to increase growth performance. Although the red muscle represents only $4 \%$ of the total weight of matrinxa, it concentrates eight times more lipids than the white muscle. Lipids are preferably used as a fuel source to support muscle contraction during the SS at low-speed (Coughlin, 2002; Richards et al., 2002). In the present study, lipid storage increased in the red muscle of matrinxa maintained under SS. This pattern of response, observed in both white and red muscle, can be considered an adaptive response of the species to the exercise. The lipid content in the muscle of fish reared under SS varies according to speed in the water. In this particular, several studies have shown a lipid increase at moderate speeds; however, at swimming speeds above 1.5 BL s ${ }^{-1}$ lipid storage can decrease significantly (Totland et al., 1987; Young and Cech, 1994; Davison, 1997; Yogata and Oku, 2000). This physiological response seems well regulated and occurs to meet the energetic needs, although it prevails as long as the animals are continuously supplied with food. The present data show that juvenile matrinxa can achieve higher growth rates as a function of both SS speeds and adequate levels of dietary protein. Such synergistic effects between these two factors have further enhanced this organic response, thus promoting greater deposition of nutrients from diet into the animal biomass.

In conclusion, juvenile matrinxa achieved higher nutrient assimilation and storage of fats and proteins when both SS speed and level of dietary protein were well adjusted. The best performance was observed in fish reared under SS at $1.5 \mathrm{BL} \mathrm{s}^{-1}$ and fed with $28 \% \mathrm{CP}$. Other studies are being carried out to improve diet quality and enhance the efficiency of nutrient transference.

\section{Acknowledgements}

The authors are thankful to the Brazilian National Council for Scientific and Technological Development
(CNPq) and the São Paulo State Foundation for Research Support (FAPESP) for sponsoring this project, and the colleagues of the Adaptive Biochemistry Laboratory, Hackbarth, A.; Honorato, G.; Almeida, L.; Fabrizzi, F.; Silva, A.A., for the logistical support.

\section{References}

Abreu, J.S.; Ochao, A.I.S.; Gonçalves, S.D.; Urbinati, E.C. 2008. Stress responses of juvenile matrinxã (Brycon amazonicus) after transport in a closed system under different loading densities. Ciência Rural 38: 1413-1417.

Arbeláez-Rojas, G.A.; Moraes, G. 2009. Sustained swimming and stocking density interaction in the performance and body composition of matrinxã Brycon amazonicus juveniles. Ciência Rural 39: 201-208 (in Portuguese, with abstract in English).

Arbeláez-Rojas, G.A.; Moraes, G. 2010. Optimization of sustaining swimming speed of matrinxã Brycon amazonicus: performance and adaptive aspects. Scientia Agricola 67: 253-373.

Association of Official Analytical Chemists [AOAC]. 1990. Official Methods of Analysis. 15ed. AOAC, Arlington, VA, USA.

Christiansen, J.S.; Ringo, E.; Jobling, M. 1989. Effects of sustained exercise on growth and body composition of first-feeding fry of Arctic charr, Salvelinus alpinus. Aquaculture 79: 329-335.

Christiansen, J.S.; Jobling, M. 1990. The behaviour and the relationship between food intake and growth and juvenile Arctic charr, Salvelinus alpinus 1., subjected to sustained exercise. Canadian Journal of Zoology 68: 2185-2191.

Coughlin, D. 2002. Aerobic muscle function during steady swimming in fish. Fish and Fisheries 3: 63-78.

Cruz-Casallas, P.E.; Medina-Robles, V.M.; Velasco-Santamaria, Y.M. 2011. Fish farming of native species in Colombia: current situation and perspectives. Aquaculture Research 42: 823-831.

Davison, W. 1997. The effects of exercise training on teleost fish, a review of recent literature. Comparative Biochemistry Physiology 117: 67-75.

Felip, O.; Blasco, J.; Ibarz A.; Martin-Perez, M.; Fernández-Borràs, J. 2013. Beneficial effects of sustained activity on the use of dietary protein and carbohydrate traced with stable isotopes $15 \mathrm{~N}$ and $13 \mathrm{C}$ in gilthead sea bream (Sparus aurata). Journal of Comparative Physiology B 183: 223-234.

Felip, O.; Ibarz, A.; Fernández-Borràs, J.; Beltrán, M.; MartínPérez, M.; Planas, J.V.; Blasco, J. 2012. Tracing metabolic routes of dietary carbohydrate and protein in rainbow trout (Oncorhynchus mykiss) using stable isotopes $\left[\left[^{13} \mathrm{C}\right]\right.$ starch and $\left[{ }^{15} \mathrm{~N}\right]$ protein): effects of gelatinisation of starches and sustained swimming. The British Journal of Nutrition 107: 834-844.

Grisdale-Helland, B.; Takle, H.; Helland, S.J. 2013. Aerobic exercise increases the utilization efficiency of energy and protein for growth in Atlantic salmon post-smolts. Aquaculture 406-407: 43-51.

Hackbarth, A.; Moraes, G. 2006. Biochemical responses of matrinxã, Brycon cephalus (Gunther, 1869) after sustained swimming. Aquaculture Research 37: 1070-1078.

Houlihan, D.F.; Laurent, P. 1987. Effect of exercise training on the performance, growth, and protein turnover of rainbow trout (Salmo gairdneri). Canadian Journal of Fisheries and Aquatic Sciences 44: 1614-1621. 
Inoue, L.A.K.A.; Santos-Neto, C.; Moraes, G. 2003. Clove oil as anesthetic for juveniles of matrinxã, Brycon cephalus (Gunther, 1869). Ciência Rural 33: 943-947.

Izel, A.C.U.; Pereira-Filho, M.; Melo, L.A.S.; Macedo, J.L.V. 2004. Evaluation of dietary protein contents for juvenile matrinxa (Brycon cephalus). Acta amazônica 34: 179-184 (in Portuguese, with abstract in English).

Jobling, M. 2001. Nutrient partitioning and the influence of feed composition on body composition. p. 354-375. In: Houlihan, D.F.; Boujard, T.; Jobling, M., eds. Food intake in fish. Blackwell Science, Oxford, UK.

Jobling, M.; Baardvik, B.M.; Christiansen, J.S.; Jørgensen, E.H. 1993. The effects of prolonged exercise training on growth performance and production parameters in fish. Aquaculture International 1: 95-111.

Jobling, M.; Tveiten, H.; Hatlen, B. 1998. Cultivation of Arctic charr: an update. Aquaculture International 6: 181-196.

Jørgensen, E.H.; Jobling, M. 1993. The effects of exercise on growth, food utilization and osmoregulary capacity of juvenile Atlantic salmon, Salmo salar. Aquaculture 110: 233-246.

Li, X.F.; Wang, Y.; Liu, W.B.; Jiang, G.Z.; Zhu, J. 2013. Effects of dietary carbohydrate/lipid ratios on growth performance, body composition and glucose metabolism of fingerling blunt snout bream (Megalobrama amblycephala). Aquaculture Nutrition 2: $1-12$.

Lovell, R.T. 1998. Nutrition and Feeding of Fish. Van Nostrand Reinhold, New York, NY, USA.

Mounic-Silva, C.E.; Leite, R.G. 2012. Abundance of young-ofthe-year migratory Characiforms in floodplain areas of the middle Solimões-Amazon river at flooding 2007/2008. Journal of Applied Ichthyology 29: 118-124.

Nahhas, R.; Jones, N.V.; Goldspink, G. 1982. Growth, training and swimming ability of young trout (Salmo gairdneri) maintained under different salinity conditions. Journal of the Marine Biological Association of the United Kingdom 62: 699-708.
Palstra, A.P.; Planas, J.V. 2011. Fish under exercise. Fish Physiology and Biochemistry 37: 259-272.

Richards, J.G.; Mercado, A.J.; Calyton, C.A.; Heigenhauser, G.J.; Wood, C.M. 2002. Substrate utilization during graded aerobic exercise in rainbow trout Oncorhynchus mykiss. Experimental Biology 205: 2067-2077.

Robinson, E.H.; Li, M.H. 1997. Low protein diets for channel catfish Ictalurus punctatus raised in earthen ponds at high density. Journal of the World Aquaculture Society 28: 224-229.

Sá, C.M.V.; Fracalossi, D.M. 2002. Dietary protein requirement and energy to protein ratio for piracanjuba (Brycon orbignyanus) fingerlings. Revista Brasileira de Zootecnia 31: 1-10 (in Portuguese, with abstract in English).

Shearer, K.D. 1994. Factors affecting the proximal composition of cultured fishes with emphasis on salmonids. Aquaculture 119: 63-88.

Totland, G.K.; Kryvi, H.; Jodestol, K.A.; Christiansen, E.N.; Tangeras, A.; Slinde, E. 1987. Growth and composition of the swimming muscle of adult Atlantic salmon, Salmo salar during long-term sustained swimming. Aquaculture 66: 299-313.

Videler, J.J. 2011. An opinion paper: emphasis on white muscle development and growth to improve farmed fish flesh quality. Fish Physiology and Biochemistry 37: 337-343.

Weatherly, A.H.; Gill, H.S. 1987. The Biology of Fish Growth, Academic Press, London, UK.

Wootton, R.J. 1998. Ecology of Teleost Fishes. 2ed. Kluwer Academic, London, UK.

Yogata, H.; Oku, H. 2000. The effects of swimming exercise on growth and whole-body protein and fat contents of fed and unfed fingerling yellowtail. Fisheries Science 66: 1100-1105.

Young, P.S.; Cech, J.J. 1994. Effects of different exercise conditioning velocities on the energy reserves and swimming stress responses in young-of-the-year striped bass, (Morone saxatilis). Canadian Journal of Fisheries and Aquatic Sciences 51: 1528-1534. 